\title{
A Macroprudential Theory of Foreign Reserve Accumulation
}

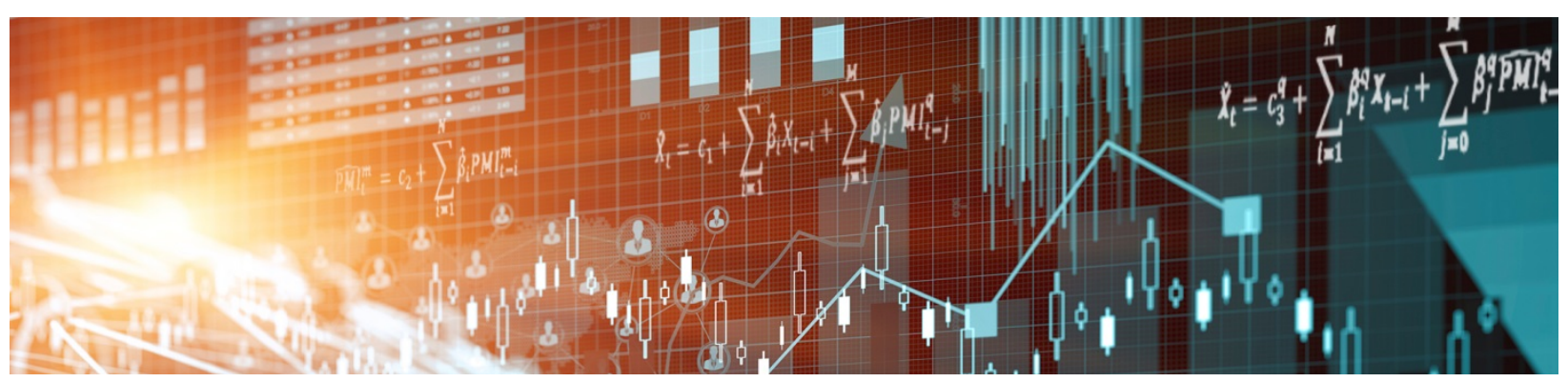

by Fernando Arce, Julien Bengui and Javier Bianchi 
Bank of Canada Staff Working Paper 2019-43

October 2019

\title{
A Macroprudential Theory of Foreign Reserve Accumulation
}

\author{
by \\ Fernando Arce $^{1}$, Julien Bengui ${ }^{2}$ and Javier Bianchi ${ }^{3}$ \\ 1 University of Minnesota \\ 2 International Economic Analysis Department \\ Bank of Canada, \\ Ottawa, Ontario, Canada K1A 0G9 \\ JBengui@bank-banque-canada.ca; \\ Université de Montréal \\ and CEPR \\ ${ }^{3}$ Federal Reserve Bank of Minneapolis \\ and NBER
}




\section{Acknowledgements}

For useful comments and suggestions, we thank Manuel Amador, Tim Kehoe, Anna Lipinska, and Nicolas Magud, as well as conference/seminar participants at the 2019 BISBoE-ECB-IMF Basel Workshop; the 2019 Midwest Macro Meetings, 2019 SED; and the University of Minnesota Trade Workshop. The views expressed herein are those of the authors and not necessarily those of the Bank of Canada, the Federal Reserve Bank of Minneapolis or the Federal Reserve System. 


\begin{abstract}
This paper proposes a theory of foreign reserves as macroprudential policy. We study an open-economy model of financial crises in which pecuniary externalities lead to overborrowing, and show that by accumulating international reserves, the government can achieve the constrained-efficient allocation. The optimal reserve accumulation policy leans against the wind and significantly reduces the exposure to financial crises. The theory is consistent with the joint dynamics of private and official capital flows, both over time and in the cross-section, and can quantitatively account for the recent upward trend in international reserves.
\end{abstract}

Bank topics: Balance of payment and components; Financial system regulation and policies; Financial stability; Foreign reserve management; International financial markets

JEL codes: D52, D62, F34, F38

\title{
Résumé
}

Cette étude propose de voir les réserves de change comme un instrument de politique macroprudentielle. Nous étudions un modèle de crises financières en économie ouverte dans lequel les externalités pécuniaires engendrent de l'endettement excessif, et démontrons qu'en accumulant des réserves de change, un gouvernement peut atteindre l'allocation efficace de second rang. Une accumulation optimale de réserves va à contrecourant du marché et réduit considérablement l'exposition aux crises financières. La théorie que nous proposons est cohérente avec la dynamique combinée des flux de capitaux privés et publics observée empiriquement, et peut expliquer quantitativement la récente tendance à la hausse des réserves de change.

Sujets : Balance des paiements et composantes; Réglementation et politiques relatives au système financier; Stabilité financière; Gestion des réserves de change; Marchés

financiers internationaux

Codes JEL : D52, D62, F34, F38 


\section{Non-technical summary}

The amount of foreign reserves held by emerging market economies has significantly increased over the past three decades. In this paper, we propose a novel explanation for this phenomenon based on a macroprudential motive. Using a model of financial crises with inefficient private borrowing, we show that reserve accumulation can correct a pecuniary externality leading to overborrowing. Managing foreign reserves can thus serve as an alternative to financial regulation to pursue macroprudential policy goals.

The macroprudential accumulation of foreign reserves achieves its objective of addressing overborrowing by leading private agents to saturate their borrowing limits up to the point where they cannot undo the government's decision to accumulate assets. To the extent that borrowing limits get relaxed when output is high, the policy therefore entails procyclical reserves and procyclical private external debt.

Our macroprudential hypothesis for reserve accumulation is supported by data for middleincome countries, as evidenced by our model's ability to generate salient cross-sectional and time-series facts regarding reserves and private external debt. First, our model predicts a simultaneous increase in reserves and private external debt following a financial liberalization episode, as observed in the data. Second, it is consistent with the positive cross-sectional association between reserve accumulation and private external debt accumulation observed in our sample of countries. Third, our model generates a positive time-series correlation of reserve growth and private external debt growth with each other, as well as with the business cycle, again as observed in our panel data. Finally, it is in line with the empirical regularity that countries resorting to fewer capital account restrictions tend to be holding more reserves. 


\section{Introduction}

Prior to the wave of financial globalization of the 1990s, central banks' holdings of international reserves represented on average less than 5 percent of GDP. By 2015, this ratio had more than tripled. This unprecedented accumulation of reserves has been the focus of a large and growing literature. Yet, despite much progress on both the theoretical and empirical fronts, accounting for the observed surge in reserves and its dispersion across countries remains a challenge. In this paper, we propose a theory of foreign reserve accumulation based on a macroprudential motive and show that it can quantitatively account for the recent buildup of international reserves while being consistent with salient cross-sectional patterns.

Our theory is motivated by a prevalent intertwined relationship between foreign reserves and private external debt, which we document in Section 2 for a sample of middle-income countries. First, concomitantly with the increase in foreign reserves, there has been an increase in private external debt. In other words, in the aggregate, the rise in official capital outflows has coincided with an increase in private capital inflows. Second, and turning to cross-sectional evidence, foreign reserve growth has been particularly high in countries that have also experienced high growth of external private debt. Third, reserve and private external debt accumulation appear to be positively correlated over time and procyclical for most countries. Fourth, reserve holdings tend to be larger for those economies with a more open capital account. We argue that these facts point to a hypothesis linking international reserves to the management of private capital flows, in line with our theory.

The environment we consider is a small open-economy model of financial crises with inefficient private borrowing. Domestic households face uninsurable income shocks and trade non-state contingent bonds denominated in foreign currency with external creditors. Households are subject to a credit constraint that depends on income, which links the borrowing capacity to the real exchange rate (Mendoza, 2002). When an adverse shock hits and the economy is sufficiently leveraged, households hit the credit constraint and become unable to smooth consumption. Households' deleveraging then leads to a further tightening of the borrowing constraint through a feedback loop between the real exchange rate and the borrowing capacity. Households fail to internalize these general equilibrium effects and overborrow relative to a constrained social optimum (Bianchi, 2011). Our main theoretical contribution in this paper is to show that the constrained-efficient allocation can be im-

plemented via reserve accumulation. While the externality problem is one of overborrowing, the optimal reserve accumulation policy leads to even larger gross private borrowing. Yet, as agents are ultimately prevented by the borrowing constraint from fully offsetting the government's foreign reserve accumulation, the economy's net foreign asset position improves and there is a reduction in the vulnerability to a financial crisis. 
The model yields a number of predictions consistent with the aforementioned empirical observations. First, regarding the interplay between private external debt and reserves, the model is capable of generating both a concomitant aggregate increase in the two variables following a financial liberalization episode, and a positive association between these variables in the cross-section of countries. Second, the model predicts procyclical reserve and private external debt accumulation and a positive correlation between inflows and outflows. This procyclicality is driven by the larger excess borrowing capacity during good times. Finally, the model implies that economies whose governments resort less to financial regulation instruments for macroprudential purposes should accumulate more reserves. Conversely, the more a government uses capital controls or other measures such as capital requirements and reserve requirements to manage the credit cycle, the less international reserves are needed.

Literature. Our paper is related to a vast literature seeking to explain the demand for international reserves. A first strand of the literature emphasizes precautionary aspects and has a long tradition going back to Kenen and Yudin (1965), Heller (1966), Clower and Lipsey (1968), Clark (1970), and Kelly (1970). Using a modern approach, these precautionary theories have focused on shocks to income or shocks to countries' access to credit markets. Durdu, Mendoza and Terrones (2009) examine how the risk of sudden stops affects the determination of net foreign asset positions. Caballero and Panageas (2008) and Jeanne and Ranciére (2011) model reserves as insurance contracts against the risk of sudden stops. In Bianchi, Hatchondo and Martinez (2018), reserves are modeled as non-state-contingent assets that provide insurance against rollover risk. Bianchi and Sosa-Padilla (2018) examine a macroeconomic stabilization channel and its interaction with a precautionary motive. Our paper shares with this line of research the broad idea that reserve accumulation is useful in anticipation of future sudden stops. ${ }^{1}$ However, it differs in that we model reserves as a policy tool designed to correct an externality affecting private borrowing decisions and systemic risk. This distinction makes our model particularly suited to study the joint dynamics of private and official capital flows.

The idea that the motive for reserve accumulation derives from the correction of an externality is also present in the literature on the mercantilist motive of reserves, which argues that reserve accumulation may be a by-product of industrial policies promoting exports in the presence of growth externalities (Rodrik, 2008; Benigno and Fornaro, 2012). ${ }^{2}$ In contrast to that literature, however, we focus on an externality that occurs directly on financial markets and leads to excessive systemic risk.

\footnotetext{
${ }^{1}$ Other related papers in this line of work include Aizenman and Lee (2007), Bacchetta, Benhima and Kalantzis (2013), Hur and Kondo (2016), and Jeanne and Sandri (2017), among others. For empirical work tackling the precautionary motive of reserves, see Edwards (1983), Aizenman and Lee (2007), Obstfeld, Shambaugh and Taylor (2010), Frankel and Saravelos (2012), Bussiere, Cheng, Chinn and Lisack (2013), and Calvo, Izquierdo and Loo-Kung (2013).

${ }^{2} J e a n n e$ (2012) also studies how reserve accumulation can alter the real exchange rate in an economy with a closed capital account for the private sector.
} 
Our paper also relates to the literature that studies foreign exchange intervention in the presence of limits to international arbitrage. Examples include Cavallino (2018), who shows how foreign exchange intervention can deal with dynamic terms of trade externalities and capital account shocks; Amador, Bianchi, Bocola and Perri (2017), who show the need to accumulate reserves to implement exchange rate policies when monetary policy faces a zero lower bound constraint; and Fanelli and Straub (2017), who characterize optimal policies when exchange rate fluctuations lead to distributional consequences. While a common theme in these papers is that international intermediaries have limited leverage capacity, as in Gabaix and Maggiori (2015), our focus is instead on frictions in domestic financial markets. In addition, a key distinction of our paper is that we study the scope for reserve accumulation due to a financial stability motive. In this respect, our paper is related to the arguments in Calvo (2006) and Obstfeld et al. (2010) and is complementary to Bocola and Lorenzoni (2017), who show that reserves can enhance the credibility of lender of last resort policies by relaxing fiscal constraints.

Our paper also relates to the literature on macroprudential policy. This literature has shown how taxes on borrowing and capital requirements can correct pecuniary externalities that generate excessive systemic risk (e.g., Lorenzoni, 2008; Bianchi, 2011; Bianchi and Mendoza, 2018; Jeanne and Korinek, 2018). We complement this literature by studying the role of international reserves as a macroprudential policy and demonstrate that the accumulation of international reserves constitutes an alternative policy tool that can substitute for the use of financial regulation policies.

Our finding that private borrowing rises as a result of the policy intervention is an aspect shared with studies arguing for the possibility of underborrowing, such as Benigno, Chen, Otrok, Rebucci and Young (2013) and Schmitt-Grohé and Uribe (2016). In Benigno et al. (2013), the government has access to a richer set of tax instruments, enabling it to relax borrowing constraints ex post, which results in more borrowing ex ante than in the laissez-faire. In Schmitt-Grohe and Uribe (2016), the government intervention induces more borrowing when there is a possibility of multiple equilibria and the bad equilibrium is selected. In contrast with these studies, our model distinguishes between private and official flows, and we find that the optimal intervention entails higher gross private borrowing but at the same time a larger net foreign asset position for the economy as a whole.

The paper is organized as follows. Section 2 outlines the motivating facts. Section 3 presents the model and the main theoretical result. Section 4 contains a quantitative analysis, and Section 5 concludes. 


\section{Motivating facts: reserves, debt, and capital mobility}

In this section, we present empirical evidence on international reserves and private external debt that illustrates the intertwined relationship between these two variables. We use data for middle-income countries from 1980 to $2015 .{ }^{3}$ The data for private external debt are from the International Debt Statistics collected by the World Bank and measure private external debt as non-publicly guaranteed external debt. ${ }^{4}$

We summarize the evidence in four facts:

FACT 1: Over the past three decades, there has been a concomitant substantial increase in private external debt and international reserves in the aggregate. Figure 1 shows the evolution of private external debt and reserves for the average GDP-weighted middle-income country from 1980 to $2015 .^{5}$ Until 1990, both international reserves and private external debt were below 5 percent of total GDP. By 2015, reserves and private external debt reached, respectively, 16.6 percent of GDP and 13.3 percent of GDP. It is worth noting that the sharp rise in private external debt contrasts with the modest decline in publicly guaranteed external debt (PGD) in the countries in our sample. Over the same time period, PGD decreased from 14.1 percent of GDP in 1980 to 13.5 percent of GDP in 2015 for the average GDP-weighted middle-income country.

FACT 2: Foreign reserve growth has been particularly high in countries that have also experienced high growth of external private debt. Figure 2 shows a scatter plot of the differences between 2015 and 1980 values of the ratios of private external debt to GDP ( $x$-axis) and reserve to GDP ( $y$-axis) for the sample of countries considered, with each dot representing a country. It documents a positive correlation between growth in reserves and growth in private external debt across countries during our sample period. ${ }^{6}$

The cross-sectional association between international reserves and private external debt is also apparent from panel regressions. Table 1 reports results from estimations of regressions of logged reserves-to-GDP ratios onto logged private external debt-to-GDP ratios. In the first two columns, we report results of pooled ordinary least squares (OLS) regressions, while in the last two, we report results of regressions with time and country fixed effects. The regressions of columns 1 and 3 include a constant, while those of columns 2 and 4 also control for the logged ratio of PGD to GDP and for

\footnotetext{
${ }^{3}$ The complete list of countries, based on data availability, is Argentina, Brazil, Cameroon, Colombia, Costa Rica, Dominican Republic, Ecuador, Egypt, El Salvador, Ghana, Guatemala, Honduras, India, Kenya, Malaysia, Mexico, Morocco, Nigeria, Pakistan, Peru, Philippines, South Africa, Sri Lanka, Thailand, Tunisia, and Turkey.

${ }^{4}$ An advantage of using data from the International Debt Statistics is that it allows us to differentiate PGD and nonPGD. This distinction is important, as some middle-income countries in our sample have large publicly owned companies that issue debt internationally.

${ }^{5}$ This trend also holds when we look at simple averages. Figure 1 excludes China.

${ }^{6}$ Obstfeld, Shambaugh and Taylor (2010) report a positive correlation between domestic private debt and reserves. We document instead the association with external debt.
} 
GDP growth. In all cases, the coefficient on private external debt is positive and statistically significant at the 1 percent confidence level, indicating a robust statistical association between private debt and reserves.

FACT 3: The accumulation of reserves and private external debt are correlated with each other over time and are procyclical for most countries. During our time period of interest (1980-2015), we find that the accumulation of international reserves and the expansion of private debt tend to correlate positively with each other as well as with real GDP growth across middle-income countries. Figure 3 displays correlations of real GDP growth with the growth rates of reserves and of private debt (panel a and b, respectively), as well as between the growth rates of reserves and private debt (panel c). Similarly to Bianchi et al. (2018), we find that reserves growth correlates positively with output growth for a wide majority of countries. We also find a positive correlation between growth of private external debt and output growth for most countries. Finally, in line with Broner, Didier, Erce and Schmukler (2013), we find that inflows of private debt correlate over time with outflows of international reserves for a majority of countries.

FACT 4: Reserve holdings tend to be larger in economies with a more open capital account. Figure 4 shows a scatter plot of the Chinn and Ito (2008) index of capital account openness and the average ratio of reserves to GDP over the 1980-2015 time period. It shows a positive correlation between reserves and capital account openness in cross-country data of middle-income countries, in line with the evidence presented by Aizenman and Lee (2007) and Bussiere et al. (2013). In other words, emerging countries that impose significant controls on international private flows of capital tend to have relatively smaller ratios of reserves to GDP than countries with more liberalized capital accounts.

To summarize the empirical evidence that motivates our theoretical analysis, we have that in the data (i) there has been a substantial increase in private external debt and international reserves in the aggregate; (ii) there is a positive correlation between reserves and private external debt in the cross-section; (iii) both reserve and private external debt accumulation tend to correlate positively with the business cycle, and with each other; and (iv) reserve levels are higher in countries with more open capital accounts. ${ }^{7}$ We next propose a theory that sheds light on the interplay between private external debt and reserves. In our model, both variables are endogenous and their dynamics are consistent with the four aforementioned facts.

\footnotetext{
${ }^{7}$ While these observations indicate positive associations, they do not point prima facie to any causality in either direction.
} 


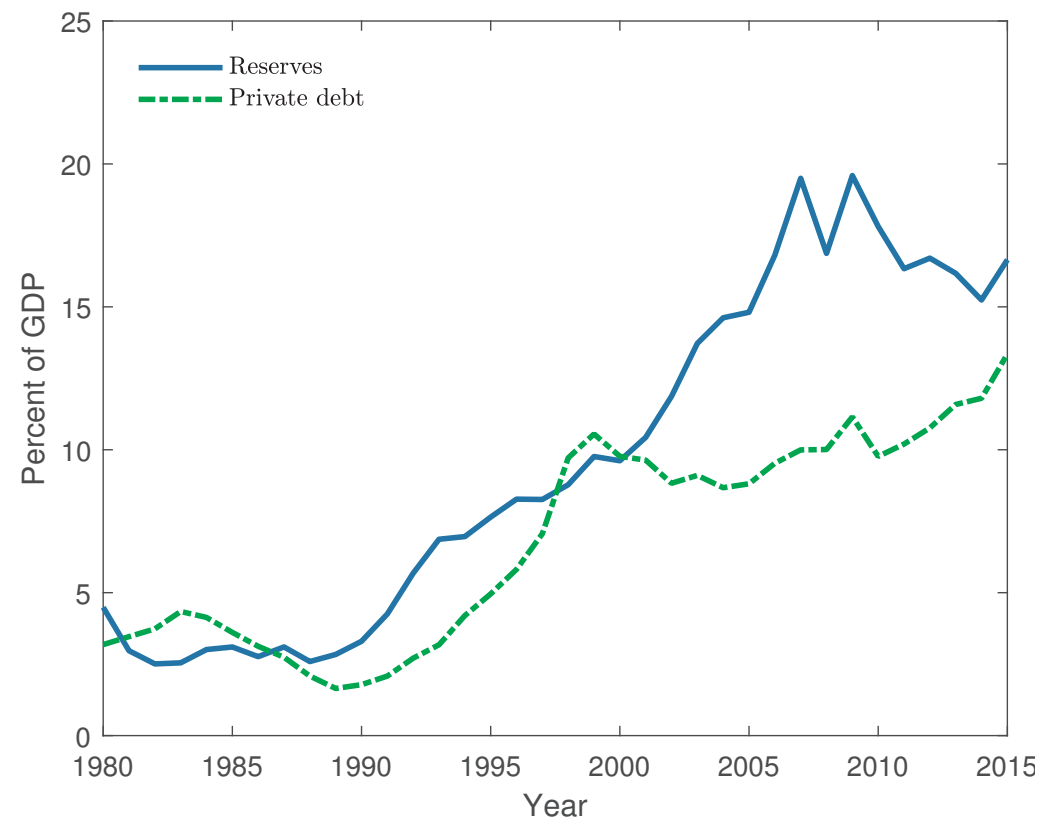

Figure 1: Reserves and private debt in the GDP-weighted average middle-income country

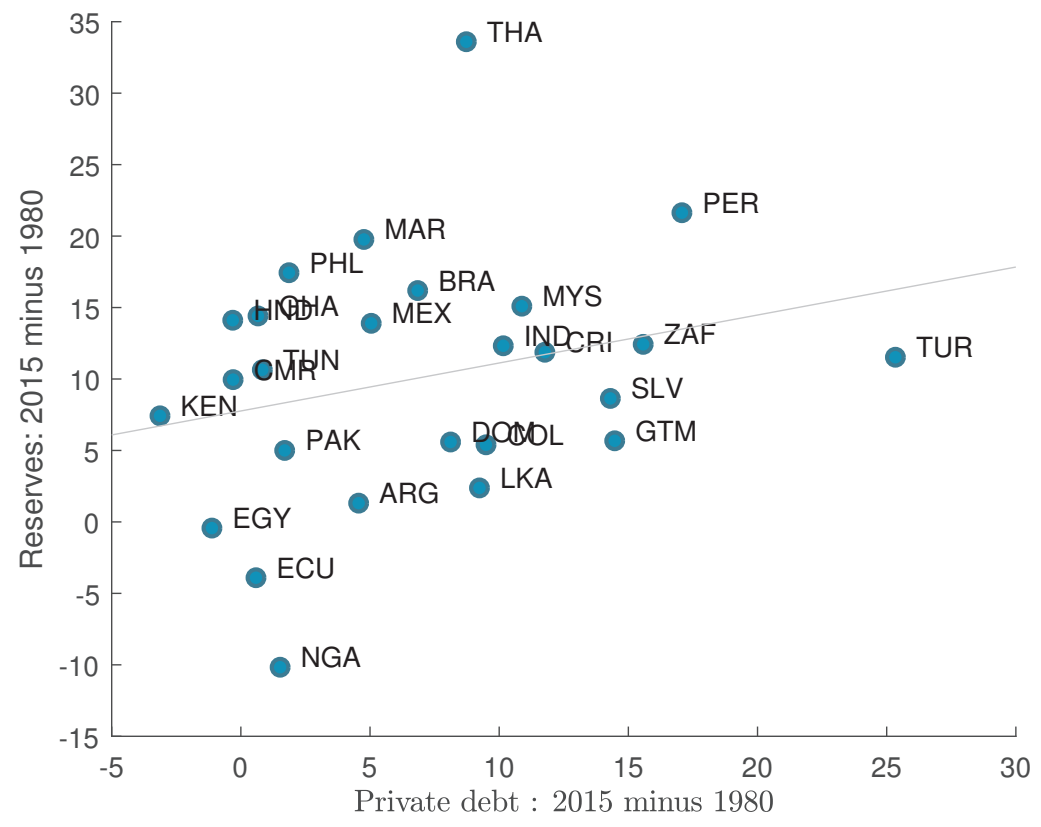

Figure 2: Private external debt to GDP and reserves to GDP: differences between 2015 and 1980 values 
Table 1: Reserves-to-GDP Ratios on Private External Debt-to-GDP Ratios (in logs)

\begin{tabular}{lllll}
\hline \hline & Reserves & Reserves & Reserves & Reserves \\
\hline & & & & \\
Private External Debt & $0.183^{* * *}$ & $0.176^{* * *}$ & $0.0526^{* * *}$ & $0.0553^{* * *}$ \\
& $(0.0237)$ & $(0.0227)$ & $(0.0203)$ & $(0.0207)$ \\
& & & & \\
Publicly Guaranteed & & $-0.450^{* * *}$ & & -0.0379 \\
External Debt & $(0.0480)$ & & $(0.0541)$ \\
& & & & -0.000146 \\
GDP Growth Rate & & $(0.00254$ & & $(0.00175)$ \\
& & & & \\
& & & & 874 \\
\hline Observations & 874 & 874 & 874 & 26 \\
Countries & 26 & 26 & 26 & FE \\
Pooled OLS/ Fixed Effects & pooled & pooled & FE & \\
\hline \hline Note: Standard errors in parentheses. ${ }^{*} p<0.1,{ }^{* *} p<0.05,{ }^{* * *} p<0.01$ &
\end{tabular}

(a) Reserves and real GDP

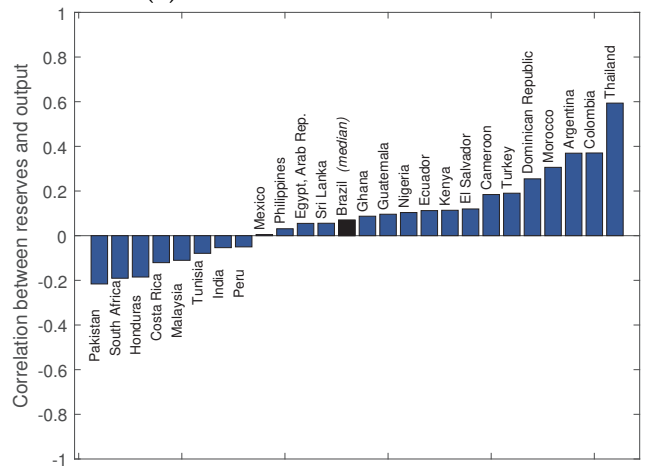

(b) Private debt and real GDP

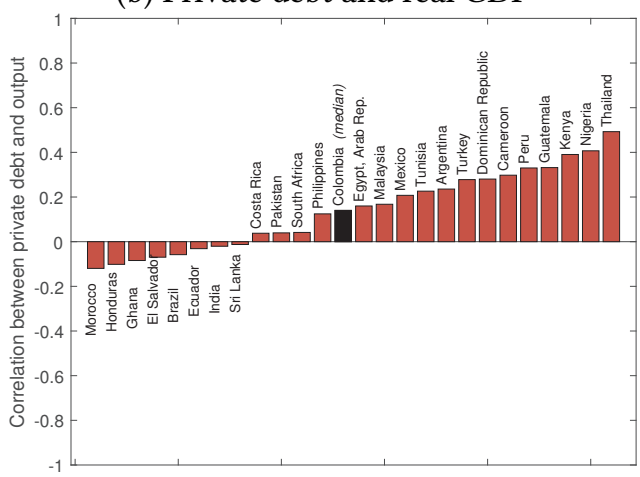

(c) Reserves and private debt

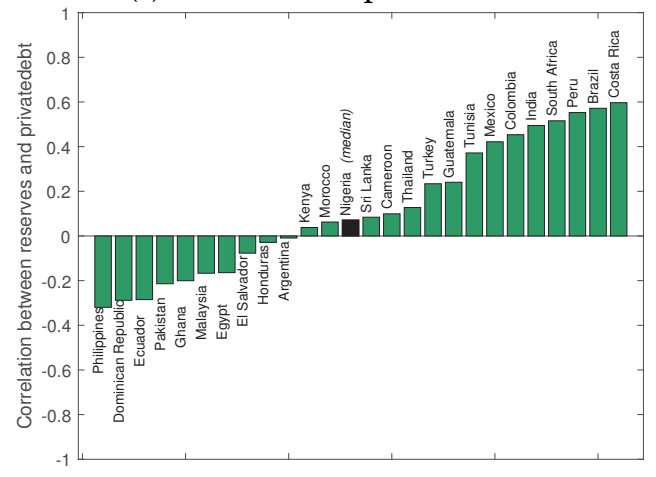

Figure 3: Correlation between the growth rates of real GDP and reserves (panel a), real GDP and private debt (panel b), and reserves and private debt (panel c) 


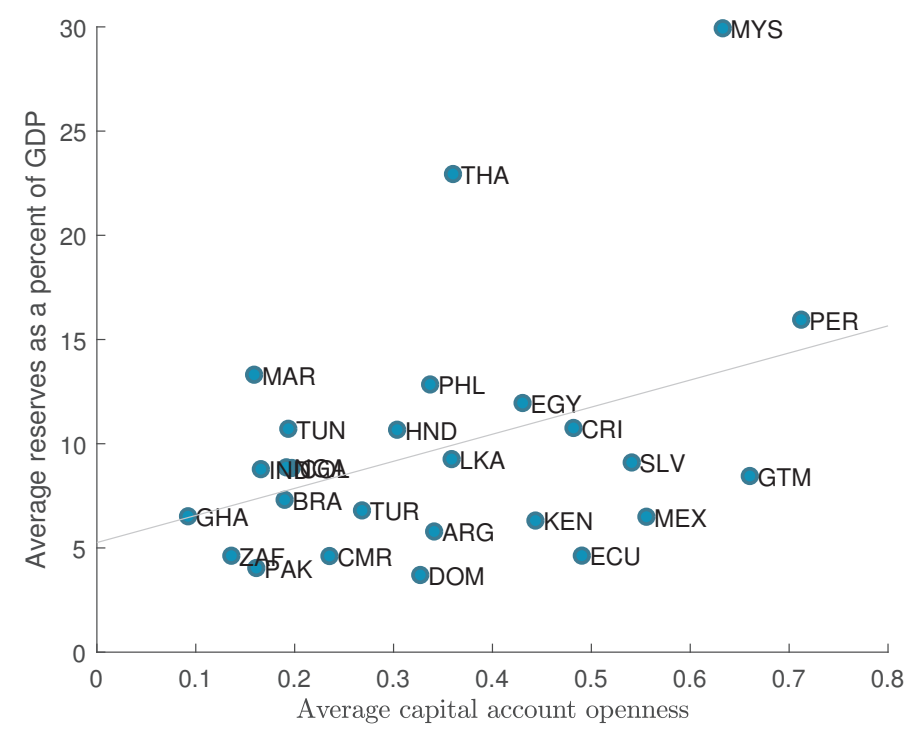

Figure 4: Average 1980-2015 reserves and Chinn and Ito (2008) capital account openness

\section{Model}

We consider a dynamic small open-economy model with tradable and non-tradable goods. The economy is populated by a continuum of identical households of unit measure that borrow externally subject to an occasionally binding borrowing constraint. We describe first the household problem, and then we analyze the competitive equilibrium and the role of international reserves.

\subsection{Household problem}

Households' preferences are given by

$$
\mathbb{E}_{0} \sum_{t=0}^{\infty} \beta^{t} u\left(c_{t}\right),
$$

where $\mathbb{E}_{0}$ is the expectation operator conditional on date 0 information; $0<\beta<1$ is a discount factor; $u(\cdot)$ is a standard increasing, concave, and twice continuously differentiable function satisfying the Inada condition; and consumption $c$ is an Armington-type constant elasticity of substitution (CES) aggregator with elasticity of substitution $1 /(\eta+1)$ between tradable goods $c^{T}$ and non-tradable goods $c^{N}$, given by

$$
c=\left[\omega\left(c^{T}\right)^{-\eta}+(1-\omega)\left(c^{N}\right)^{-\eta}\right]^{-\frac{1}{\eta}}, \eta>-1, \omega \in(0,1) .
$$


In each period, households receive a random endowment of tradable goods $y_{t}^{T}$ and a fixed endowment of non-tradable goods $y^{N}$. The endowment of tradables follows a first-order Markov process. We use the tradable good as the numeraire.

Households can save and borrow using a one-period non-state-contingent bond $b$ denominated in units of tradables paying an interest rate $R$, which is exogenously determined in international capital markets. ${ }^{8}$ Their budget constraint, in units of tradables, is given by

$$
b_{t}+c_{t}^{T}+p_{t}^{N} c_{t}^{N}=\frac{b_{t+1}}{R}+y_{t}^{T}+p_{t}^{N} y^{N}-T_{t},
$$

where $p_{t}^{N}$ is the price of non-tradable goods and $T_{t}$ is a lump-sum tax. In addition, households face a credit constraint given by

$$
\frac{b_{t+1}}{R} \leq \kappa_{t}\left(y_{t}^{T}+p_{t}^{N} y^{N}\right)
$$

This credit constraint captures in a parsimonious way the empirical fact that income is critical in determining credit-market access, and it has been shown to be capable of accounting for the dynamics of capital flows in emerging markets (e.g., Mendoza, 2002). Non-tradable goods enter the collateral constraint because while foreign creditors do not value the non-tradable good, they can sell it in exchange for tradable goods in the domestic market, after seizing these goods in the event of a default. ${ }^{9}$ We allow for a shock to the degree of imperfect enforcement $\kappa_{t}$, which we refer to as a financial shock. One interpretation of this shock is that it captures fluctuations in lenders' perceptions about households' ability to repay.

Households choose consumption and borrowing to maximize their utility (1) subject to their budget (2) and credit constraint (3), taking prices and taxes as given. Their optimality conditions are given by

$$
\begin{aligned}
p_{t}^{N} & =\frac{1-\omega}{\omega}\left(\frac{c_{t}^{T}}{c_{t}^{N}}\right)^{\mu+1}, \\
u_{T}(t) & =\beta R \mathbb{E}_{t} u_{T}(t+1)+\mu_{t} \quad \text { with } \mu_{t}=0 \text { if } b_{t+1} / R<\kappa_{t}\left(p_{t}^{N} y^{N}+y_{t}^{T}\right),
\end{aligned}
$$

where $u_{T}(t)$ is shorthand notation for $\frac{\partial u}{\partial c} \frac{\partial c}{\partial c^{T}}$ and $\mu_{t}$ denotes the Lagrange multiplier on the borrowing constraint. Condition (4) is a static optimality condition equating the marginal rate of substitution between tradable and non-tradable goods to their relative price. Condition (5) is the household's Eu-

\footnotetext{
${ }^{8}$ Assuming no foreign inflation, it is equivalent to denominating the bonds in foreign currency, capturing the liability dollarization phenomenon.

${ }^{9}$ The credit constraint can be derived endogenously from a problem of limited enforcement under two assumptions. First, households can default at the end of the current period. Second, upon default, foreign creditors can seize a fraction $\kappa_{t}$ of the current income, and households immediately regain access to credit markets. The current, rather than the future, price appears in the constraint because the opportunity to default occurs at the end of the current period, before the realization of future shocks (see Bianchi and Mendoza, 2018, for a derivation of a similar constraint).
} 
ler equation for bonds. If $\mu_{t}>0$, the marginal utility benefits from increasing tradable consumption today exceed the expected marginal utility costs from borrowing one unit and repaying next period.

\subsection{Government}

The government accumulates international reserves $A_{t+1} \geq 0$ and finances them with lump-sum taxes and existing holdings of reserves $A_{t}$. Its budget constraint is given by

$$
\frac{A_{t+1}}{R}=T_{t}+A_{t}
$$

The assumption that reserves are non-negative (i.e., we do not allow the government to borrow externally) is mainly for simplicity. What is important for our analysis is that there is a finite limit on external government borrowing. Absent a constraint on external borrowing, the government could use its borrowing capacity to bypass the borrowing constraint on households using lump-sum transfers and taxes. ${ }^{10}$

\subsection{Competitive equilibrium}

The market clearing for non-tradable goods is

$$
c_{t}^{N}=y_{t}^{N}
$$

We can now define a competitive equilibrium for any government policies. Given $\left\{T_{t}, A_{t+1}\right\}_{t \geq 0}$, a competitive equilibrium is defined as a stochastic sequence of prices $\left\{p_{t}^{N}\right\}_{t \geq 0}$ and households' policies $\left\{c_{t}^{T}, c_{t}^{N}, b_{t+1}\right\}_{t \geq 0}$ such that (i) households maximize their utility (1) subject to the sequence of budget constraints (2) and credit constraints (3), taking as given prices and government policies; (ii) the government budget constraint (6) is satisfied; and (iii) the market clears for non-tradable goods (7).

It will be useful to combine the household and the government budget constraint together with market clearing for non-tradables. With this, we obtain the consolidated resource constraint for tradable goods:

$$
c_{t}^{T}+\frac{A_{t+1}-b_{t+1}}{R}=y_{t}^{T}+A_{t}-b_{t} .
$$

This condition illustrates that from the perspective of the small open economy, official reserves and

\footnotetext{
${ }^{10}$ We could allow the government to finance reserve accumulation with domestic debt, in addition to taxation (motivated by tax-smoothing considerations). In this extended setting, the government would offer a high interest rate on domestic bonds to alter households' intertemporal consumption. Provided that investors are excluded from the domestic bond market, the allocations would be isomorphic, with the domestic rate being determined by $\frac{u_{T}(t)}{\beta u_{T}(t+1)}$. If foreign investors had access to domestic bonds, they would earn a rent at the expense of the small open economy generating an extra cost from interventions (see Amador et al., 2017; Fanelli and Straub, 2017).
} 
household-held bonds are perfect substitutes. Absent the credit constraint (3), Ricardian equivalence would hold and the amount of foreign reserves accumulated by the government would be completely irrelevant. However, as we show below, the presence of the credit constraint (3) makes reserve accumulation both effective and desirable.

\subsection{Constrained efficiency}

The previous section defined a competitive equilibrium in which households optimize over consumption and savings, taking the price of non-tradables and government policies as given. We now turn to a welfare analysis and consider a social planner who makes collective borrowing decisions on behalf of the households. The analysis is motivated by a pecuniary externality that arises because households' ability to borrow depends on the market-determined price of non-tradable goods. In particular, households do not internalize that by borrowing more in the present and consuming less in the future, they put downward pressure on the future price of non-tradables and thereby contribute to tightening other agents' credit constraints. Following the analysis of constrained efficiency in Bianchi (2011), we consider the problem of a constrained social planner who directly chooses the economy's debt subject to the borrowing constraint and allows goods markets to clear competitively. That is, the planner borrows from the rest of the world and transfers the net proceeds of its borrowing or savings decisions to households, who choose their allocation of consumption between tradable goods and non-tradable goods in a competitive way.

The constrained social planner's optimization problem in recursive form is given by:

$$
\begin{aligned}
V\left(b, y^{T}, \kappa\right)= & \max _{b^{\prime}, c^{T}} u\left(c\left(c^{T}, y^{N}\right)\right)+\beta \mathbb{E} V\left(b^{\prime}, y^{T^{\prime}}, \kappa^{\prime}\right) \\
& \text { subject to } \\
b+c^{T}= & y^{T}+\frac{b^{\prime}}{R}, \\
\frac{b^{\prime}}{R} \leq \kappa & {\left[y^{T}+\frac{1-\omega}{\omega}\left(\frac{c^{T}}{y^{N}}\right)^{\eta+1} y^{N}\right] . }
\end{aligned}
$$

The planner's first-order condition for debt yields the Euler equation:

$$
u_{T}(t)+\mu_{t}^{\star} \Psi_{t}=\beta R \mathbb{E}_{t}\left(u_{T}(t+1)+\mu_{t+1} \Psi_{t+1}\right)+\mu_{t}^{\star},
$$

where $\mu_{t}^{\star}$ is the non-negative Lagrange multiplier on the planner's borrowing constraint. The term $\Psi_{t} \equiv \kappa_{t}\left(p_{t}^{N} c_{t}^{N}\right) /\left(c_{t}^{T}\right)(1+\eta)$ represents how much the collateral value changes in equilibrium when there is a change in tradable consumption and is the product of three terms: the collateral parameter $\kappa_{t}$, the share of non-tradable consumption, and the inverse of the elasticity of substitution. 
There are two wedges in this planner's first-order condition with respect to the Euler equation in the decentralized equilibrium (5). On the left-hand side, the term $\mu_{t} \Psi_{t}$ captures that an increase in aggregate consumption at time $t$ helps to relax the credit constraint when it binds in the current period. On the right-hand side, the same term updated one period captures how an increase in borrowing today reduces consumption tomorrow and tightens tomorrow's credit constraint. Thus, whenever the credit constraint is not currently binding but is expected to bind with strictly positive probability next period, households fail to internalize that higher current borrowing imposes a negative externality on the rest of the economy in the future and hence tend to "overborrow" relative to a constrained-efficient outcome.

\subsection{Reserve accumulation}

In this section, we prove that the constrained-efficient allocations can be decentralized via an appropriate policy of reserve accumulation. This result complements previously established decentralizations via taxes on debt (Bianchi, 2011). ${ }^{11}$ One potential advantage of the implementation with reserves is that capital controls are often associated with leakages that undermine their effectiveness (Bengui and Bianchi, 2018). This may make reserve accumulation a more attractive policy to pursue in practice and can, in fact, rationalize why governments so often resort to reserves as a primary macroeconomic policy tool.

To establish our result, it is convenient to impose the following assumption.

Assumption 1. Consumption is a Cobb-Douglas aggregator $c=\left(c^{T}\right)^{\omega}\left(c^{N}\right)^{1-\omega}$, and the credit constraint parameter satisfies $\kappa_{t}(1-\omega)<1$.

This assumption, which implies unitary elasticity of substitution between tradables and nontradables, simplifies the analytics of our theoretical characterization. It guarantees that in any equilibrium, an increase in aggregate consumption by one unit does not relax the credit constraint by more than one unit in equilibrium. In our quantitative analysis of Section 4, however, we depart from a unitary elasticity and obtain numerical results that are identical to those of the theoretical analysis that follows.

Our main result is summarized in the following proposition.

Proposition 1. Suppose Assumption 1 holds. Consider the solution to the constrained-efficient planning problem $\left\{c_{t}^{\star T}, b_{t+1}^{\star}, p_{t}^{\star N}, c_{t}^{\star N}\right\}$ and initial conditions $\left(b_{0}, A_{0}\right)$ for a competitive equilibrium such that $b_{0}^{\star}=b_{0}-A_{0}$. Then $\left\{c_{t}^{\star^{T}}\right\}$ is part of a decentralized equilibrium with reserve accumulation if the

\footnotetext{
${ }^{11}$ Amador et al. (2017) and Fanelli and Straub (2017) also analyze the connection between capital controls and foreign exchange intervention, but the equivalence we highlight here is not present in their setups.
} 
government follows the policy $\left\{A_{t+1}^{R}\right\}$ that satisfies

$$
A_{t+1}^{R}=-b_{t+1}^{\star}+R\left[A_{t}^{R}-b_{t}+b_{t}^{\star}+\kappa_{t}\left(y_{t}^{T}+p_{t}^{\star N} y^{N}\right)\right] \quad \forall t \geq 0
$$

with initial conditions $A_{0}^{R}=A_{0}$ and $b_{0}^{R}=b_{0}$.

Proof. The proof is by construction and uses the first-order conditions as they are necessary and sufficient. We start by conjecturing that the agent's credit constraint (3) holds with equality. Using the credit constraint with equality, together with the reserve accumulation policy (13) and the market clearing for non-tradable goods (7) in the household's budget constraint, we obtain

$$
c_{t}^{T}=y_{t}^{T}+\frac{b_{t+1}^{\star}}{R}-b_{t}^{\star}=c^{T}{ }_{t}^{\star} .
$$

Hence, under the proposed reserve accumulation policy, the constrained-efficient consumption plan is achieved. We are left to show that under the conjectured private borrowing policy, the household's Euler equation and complementary slackness conditions are satisfied. From the private household's Euler equation (5), we have

$$
\mu_{t}=u_{T}(t)-\beta R \mathbb{E}_{t} u_{T}(t+1) .
$$

From the planner's Euler equation (12), we also have

$$
\mu_{t}^{*}=u_{T}(t)-\beta R \mathbb{E}_{t} u_{T}(t+1)-\beta R \mathbb{E}_{t} \Psi_{t+1} \mu_{t+1}^{\star}+\mu_{t}^{\star}\left[\kappa_{t}(1-\omega)\right] .
$$

Using the fact that consumption allocations are the same, we can combine the last two equations to obtain

$$
\mu_{t}=\beta R \mathbb{E}_{t} \kappa_{t}(1-\omega) \mu_{t+1}^{\star}+\mu_{t}^{\star}\left[1-\kappa_{t}(1-\omega)\right] \geq 0,
$$

where the last inequality follows from Assumption 1 . Since $\mu_{t} \geq 0$ and $b_{t+1} / R=\kappa_{t}\left(y_{t}^{T}+p_{t}^{\star^{N}} y^{N}\right)$, the private household's complementary slackness condition is satisfied. Therefore, under the proposed policy, all household optimality conditions and market clearing conditions are satisfied with consumption coinciding with its value in the constrained-efficient allocation.

The reserve accumulation policy described above implements the same level of tradable consumption as in the constrained-efficient allocation. Because non-tradable consumption is equal to the endowment in both cases, it follows that this policy achieves the same level of welfare. This policy achieves the same consumption allocations by effectively pushing private agents against their credit constraint whenever consumption in the laissez-faire economy would be above its level in the constrained-efficient allocation, absent any policy. As households attempt to maintain their de- 
sired current consumption, they try to offset the increase in foreign assets by the government by borrowing, up to the point where their credit constraint binds.

Under this implementation, the borrowing constraint holds with equality at all times with foreign reserve intervention. It binds strictly, however, only when there is a strictly positive probability of a binding credit constraint in the subsequent period. ${ }^{12}$ Finally, notice that if the credit constraint is binding in the constrained-efficient allocation, no reserves are carried forward (i.e., the reserve stock gets fully depleted). In the appendix, we also provide a dual result by which the optimal accumulation of international reserves yields the constrained-efficient allocations. Moreover, we show that this policy is time consistent.

Simple illustration. To shed further light on the mechanics of this implementation, it is useful to consider a one-time intervention at date $t$ starting from the laissez-faire economy. The private sector's response to a one-time reserve accumulation $A_{t+1} \geq 0$ by the government is given by

$$
\mathcal{B}_{t+1}\left(A_{t+1}\right)= \begin{cases}A_{t+1}-R\left(A_{t}-b_{t}+c_{t}^{T}-y_{t}^{T}\right) & \text { for } A_{t+1}<\bar{A}_{t+1} \\ -R \kappa_{t} \frac{\frac{1-\omega}{\omega} \frac{A_{t+1}}{R}+\frac{1}{\omega} y_{t}^{T}-\frac{1-\omega}{\omega}\left(-b_{t}+A_{t}\right)}{\left(R-\kappa_{t} \frac{1-\omega}{\omega}\right)} & \text { for } A_{t+1} \geq \bar{A}_{t+1},\end{cases}
$$

where $\bar{A}_{t+1} \equiv R\left(A_{t}-b_{t}\right)+\left(R-\kappa_{t} \frac{1-\omega}{\omega}\right) c_{t}^{T l f}-\left(R+\kappa_{t}\right) y_{t}^{T}$ and $c_{t}^{T l f}$ denote the consumption choice of households absent the intervention.

To satisfy their private Euler equation, households want to achieve a given amount of current tradable consumption $c_{t}^{T l f}$, so for small levels of reserve accumulation by the government, they react to the negative transfer (expected to be offset by a positive future transfer) by a one-to-one increase in debt, following a Ricardian equivalence type of logic. But for official reserve accumulations above a threshold $\bar{A}_{t+1}$, the private debt level required to offset the negative transfer is so large that it violates the credit constraint (3). In fact, above the threshold, more reserves contract the borrowing capacity of the economy and lead to less private debt rather than more private debt.

On the other hand, to achieve the level of consumption prevailing in the constrained-efficient allocation $c^{\star T}{ }_{t}^{T}<c_{t}^{T l f}$, the government needs to implement a level of net foreign assets of $b_{t+1}^{\star}$ going forward. Therefore, one can think of its best response to the private sector's borrowing choice $b_{t+1}$

\footnotetext{
${ }^{12}$ In a state in which the credit constraint is not expected to bind next period under the constrained-efficient allocation, we can show that implementing this allocation can be guaranteed by following any policy satisfying $A_{t+1} \leq A_{t+1}^{R}$. The logic is that in those states the anticipation that the constrained-efficient consumption will be implemented in the future leads to a current consumption equal to the constrained-efficient even without intervention.
} 
as the level of official reserves given by ${ }^{13}$

$$
\mathcal{A}_{t+1}\left(b_{t+1}\right)=b_{t+1}-b_{t+1}^{\star}
$$

In other words, the government increases reserve accumulation one to one with increases in private indebtedness.

The constrained-efficient outcome is achieved in period $t$ when both the private sector and the government play their best response, taken as given the choice of the other player. This scenario is illustrated in Figure 5. The solid line represents the private sector's best response $\mathcal{B}_{t+1}\left(A_{t+1}\right)$, and the dashed line represents the government's best response $\mathcal{A}_{t+1}\left(b_{t+1}\right)$. The equilibrium is reached at point $\left(A_{t+1}^{R}, b_{t+1}^{R}\right)$, where private households accept a tradable consumption level $c_{t}^{\star T}$ only because they are forced to do so by the government's transfer policy and their binding credit constraint. At that point, official reserves are positive and private indebtedness is higher than in the laissez-faire, but the economy's net foreign asset position has improved relative to the laissez-faire.

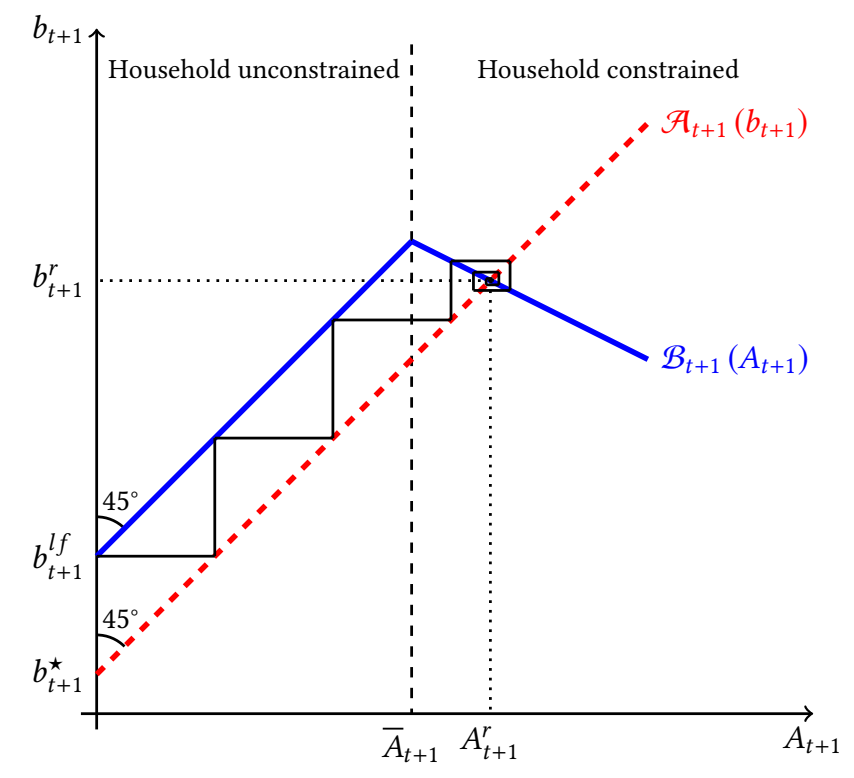

Figure 5: Implementation when private households are unconstrained in the absence of reserve accumulation

When, in contrast, the planner's Euler equation binds at date $t$, privately and socially optimal consumption coincides, and the constrained-efficient consumption allocation is implemented with full reserve depletion $\left(A_{t+1}=0\right)$. In that case, positive reserve accumulation would result in even lower, and thus suboptimal, consumption. This case is illustrated in Figure 6.

\footnotetext{
${ }^{13}$ To be precise, this policy represents the government's best response under the conjecture that the constrainedefficient allocation is also implemented from date $t+1$ onward. However, this does not alter the logic behind the implementation.
} 


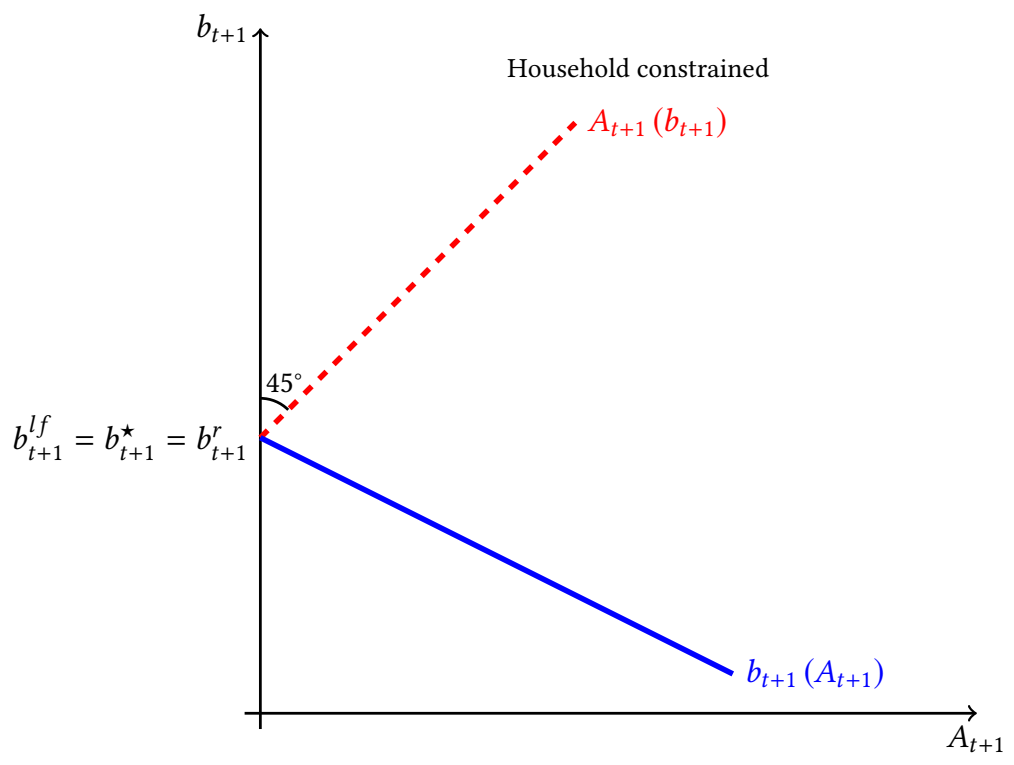

Figure 6: Implementation when private households are constrained in the absence of reserve accumulation

\section{Quantitative analysis}

\subsection{Calibration}

We calibrate the model using data for Mexico, a common choice in studies of reserve accumulation (e.g., Bianchi et al., 2018). In our calibration strategy, we assume that Mexico was in the ergodic distribution of our laissez-faire economy in the first part of the sample (1970-2000). This time period is used to calibrate the country parameters by matching steady state averages to the relevant macro moments from the data. We then study how the increase in debt and reserves we witnessed in the second half of the sample (2001-2015) can be interpreted as the result of a transition to the ergodic distribution of an economy with an optimal foreign reserve intervention.

The time period is one year. A first subset of parameters is set using standard values from the literature: $\sigma=2, r=0.04,1 /(\eta+1)=0.83$; and the endowment process is estimated using the Hodrick-Prescott filtered cyclical component of tradable GDP for Mexico. ${ }^{14}$ We assume a first-order autoregressive process for the cyclical component: $\ln y_{t}^{T}=\rho \ln y_{t-1}^{T}+\varepsilon_{t}$ with $\varepsilon_{t} \sim N\left(0, \sigma_{\varepsilon}\right)$, and estimate values of $\rho=0.46$ and $\sigma_{\varepsilon}=0.032$.

The value of $\omega$ is set so as to replicate the share of non-tradable GDP in the data, which is 55 percent. In a steady state with a mean value of debt of $\bar{b}=32$ percent of GDP to be calibrated below,

\footnotetext{
${ }^{14}$ We define tradable GDP as industrial value added in the World Development Indicators database for Mexico for the 1965-2017 time period.
} 
we have that the value of $\omega$ is given by $\frac{\bar{p}^{N} y^{N}}{\bar{p}^{N} y^{N}+y^{T}}=0.55$ where $\bar{p}^{N}=\frac{1-\omega}{\omega} \frac{y^{T}-\bar{b} r}{y^{N}}$. Normalizing the average tradable and non-tradable endowments to one, we obtain $\omega=0.45$.

We assume that the process for $\kappa_{t}$ follows an autoregressive (AR) (1) process with mean $\bar{\kappa}$ and volatility $\sigma_{\kappa}$. The parameters $\left\{\beta, \bar{\kappa}, \sigma_{\kappa}\right\}$ are set so that the economy without government intervention matches key moments of the Mexican data from 1970 to 2000. The three moments we target are the average net foreign asset position, the probability of a financial crisis, and the standard deviation of the current account-to-GDP ratio. In both the model and the data, financial crises are defined as episodes in which the current account increases by more than two standard deviations above its mean. The model equivalent of the current account as a percentage of GDP is $\frac{b_{t}-b_{t+1}}{p_{t}^{N} y_{t}^{N}+y_{t}^{T}}$. This calibration yields $\beta=0.93, \bar{\kappa}=0.35$, and $\sigma_{\kappa}=0.033$. The calibration is summarized in Table 2 .

Table 2: Parameter Values

\begin{tabular}{lll}
\hline \hline & Value & Source/Targets \\
\hline Interest Rate & $r=0.04$ & Standard value \\
Risk Aversion & $\sigma=2$ & Standard value \\
Elasticity of Substitution & $1 /(1+\eta)=0.83$ & Standard value \\
Weight on Tradables in CES & $\omega=0.45$ & Share of tradable output $=45 \%$ \\
\hline Discount Factor & $\beta=0.93$ & Average NFA-GDP ratio $=-32.0 \%$ \\
Financial Shock Mean & $\bar{\kappa}=0.35$ & Frequency of crises $=5.1 \%$ \\
Financial Shock Variance & $\sigma_{\kappa}=0.033$ & Standard deviation of the current account $=0.023$ \\
\hline
\end{tabular}

\subsection{Reserves and gross debt}

We start by describing the workings of the model through an analysis of the policy functions for reserve accumulation and debt. We will argue that the policy intervention with reserves differs drastically from the tax-based intervention that is the focus in the literature. We also show that the reserve intervention results in substantial changes in private debt accumulation, highlighting the importance of examining gross positions.

Policy function for reserves. Figure 7 presents the optimal reserve accumulation policy as a function of the shocks the economy faces and the current value of debt. In panel (a), the amount of reserves is shown as a fraction of the tradable endowment, for the mean value of $\kappa$ and for two possible values of beginning-of-period debt. In panel (b), the amount of reserves is shown as a function of the financial shock, for the mean value of $y^{T}$, again for two possible values of debt. In both cases, reserves are reported as a function of average GDP. (Unless otherwise noted, we do this for both reserves and debt throughout the paper.) 
Figure 7 shows that the government finds it optimal to hold more reserves in good times, that is, when income is high or when financial conditions are less stringent. The intuition for these results is that when the amount that households can borrow rises (because of either higher $y^{T}$ or higher $\kappa)$, the government needs to accumulate more reserves to close the gap between the net amount of borrowing desired by the planner and the borrowing capacity of households. Similarly, when beginning-of-period debt is lower, households are further away from the constraint-they want to borrow less and they have more spare borrowing capacity-and the government accumulates more reserves.

(a) As a function of income

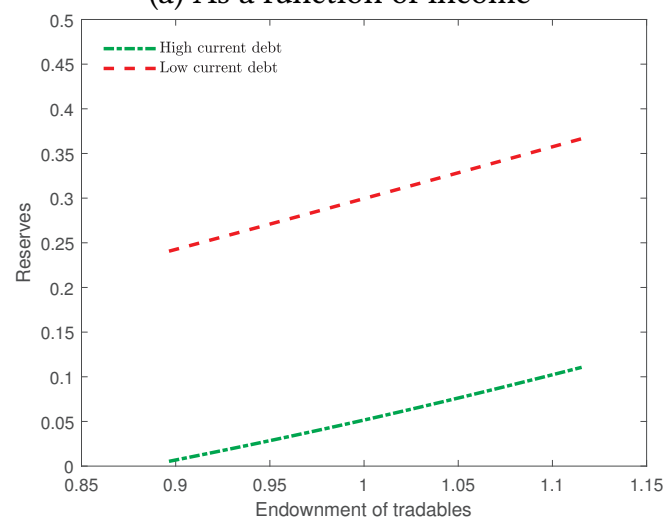

(b) As a function of $\kappa_{t}$

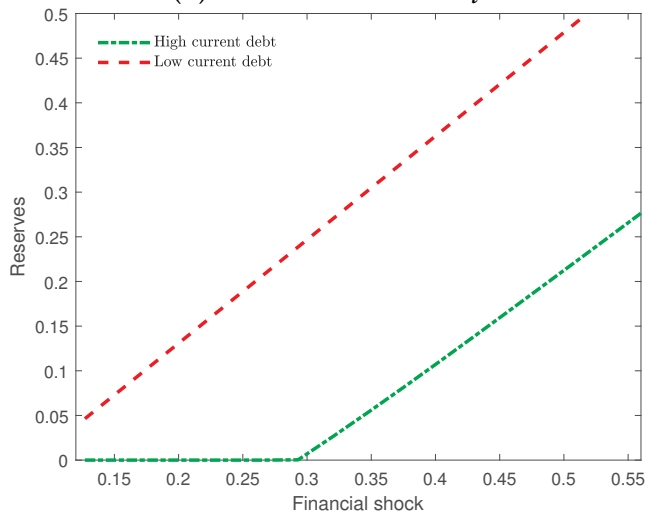

Figure 7: Policy function for reserves

Comparison with taxes on debt. An important fact that motivated our analysis was that countries with fewer restrictions on capital accounts appear to hold larger amounts of reserves (fact 4). In the model, a government that uses financial regulation with the financial stability goal of making agents internalize the pecuniary externality has no need for reserve accumulation. Likewise, a government that accumulates reserves does not need to impose financial regulation. Our model hence predicts that reserves and taxes on debt are substitutes, in line with the data, where countries that impose more restrictions on capital mobility are found to accumulate fewer reserves than countries that impose few restrictions on the capital account. ${ }^{15}$

It is interesting to contrast the properties of the reserve intervention with those of an alternative financial regulation-based policy to implement the constrained-efficient allocations. Figure 8 again displays policy functions for reserves, but this time together with policy functions for the optimal tax on debt. ${ }^{16}$ While both respond to a macroprudential motive and are passive when the constraint is already binding (both taxes on debt and reserve holdings are zero in this case), they differ markedly in terms of their cyclical properties. While reserves tend to increase with output, the tax on debt

\footnotetext{
${ }^{15}$ In the model, this relationship is of course too stark, as we abstract from other reasons to accumulate reserves.

${ }^{16}$ We apply the optimal borrowing tax formula of Bianchi (2011).
} 
tends to decrease with output. The reason for the latter is that when output is low, agents have stronger incentives to borrow, leading to a higher probability of a binding borrowing constraint in the future; a higher tax on debt is thus required when output is low. ${ }^{17}$

(a) Tax on debt and output

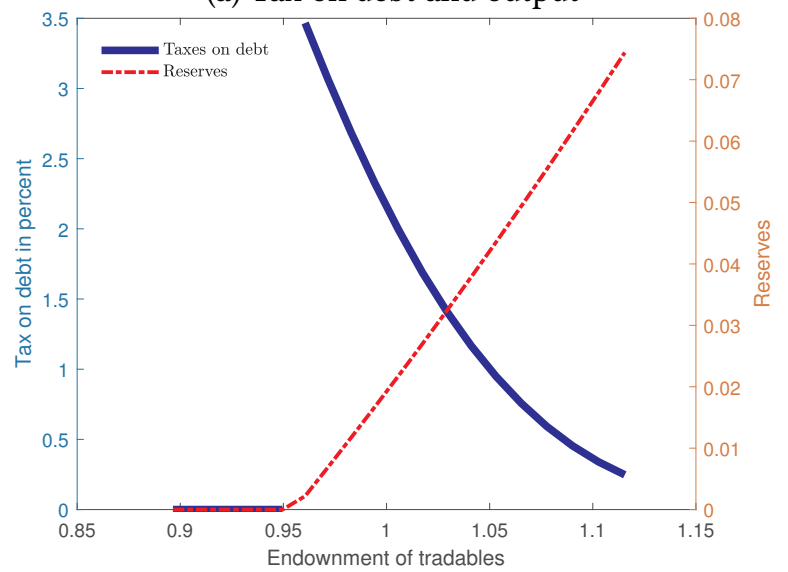

(b) Tax on debt and financial shock

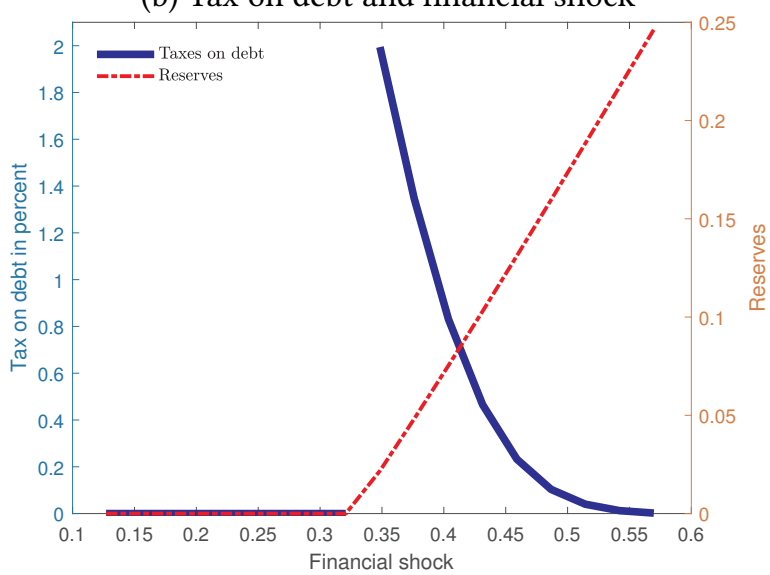

Figure 8: Reserve accumulation vs. financial regulation

Policy functions for gross private debt. We now show how the profile of private debt depends critically on the government intervention. Figure 9 shows the law of motion for $b^{\prime}$ and its ergodic distribution for three economies: (i) laissez-faire, (ii) constrained-efficient and (iii) foreign reserve intervention. ${ }^{18}$ Panel (a) shows that when current debt is high enough, the borrowing constraint binds and all three econmies have the same end-of-period debt. For low debt levels, however, debt choices differ: the constrained-efficient economy is the one in which the least amount of debt is accumulated, followed by the laissez-faire economy and the economy with foreign reserve intervention. In line with these results, panel (b) shows that the ergodic distribution of gross private indebtedness is shifted to the right in the economy with foreign reserve intervention compared with the other two economies.

A finding that stands out is that gross indebtedness is higher under the foreign reserve intervention than in the laissez-faire economy. ${ }^{19}$ Interestingly, this result emerges even though the laissez-faire economy features overborrowing with respect to the constrained-efficient allocation. The answer to this apparent puzzle is that the increase in gross indebtedness in the economy with the optimal foreign reserve intervention is more than offset by the larger stock of reserves accumu-

\footnotetext{
${ }^{17}$ The result that taxes have a negative correlation with output is emphasized in Schmitt-Grohé and Uribe (2017) and Bianchi and Mendoza (2018). Flemming, L'Huillier and Piguillem (2019) show that persistent shocks to income growth can alter the sign of the cyclicality.

${ }^{18}$ By "constrained-efficient," we mean the solution to the problem described in (9)-(11), while by "foreign reserve intervention," we mean the implementation of the constrained-efficient allocation presented in Section 3.5.

${ }^{19}$ In the state space, this occurs technically for all values of debt except those at which the borrowing constraint is binding under laissez-faire but not under constrained-efficiency.
} 
lated by the government. That is, the laissez-faire economy still displays a lower net foreign asset position than the economy with the optimal reserve intervention. This "underborrowing" result is thus different from the one highlighted by Benigno et al. (2013). In that paper, the laissez-faire economy also issues too little debt; but critically it has a higher net foreign asset position relative to an economy in which the government has access to ex post policies.

(a) Policy function for debt

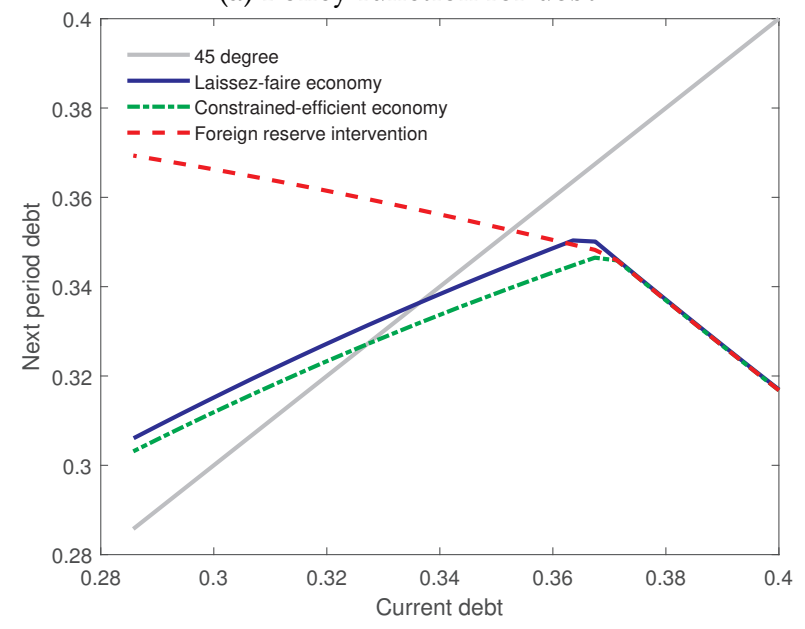

(b) Ergodic distribution of debt

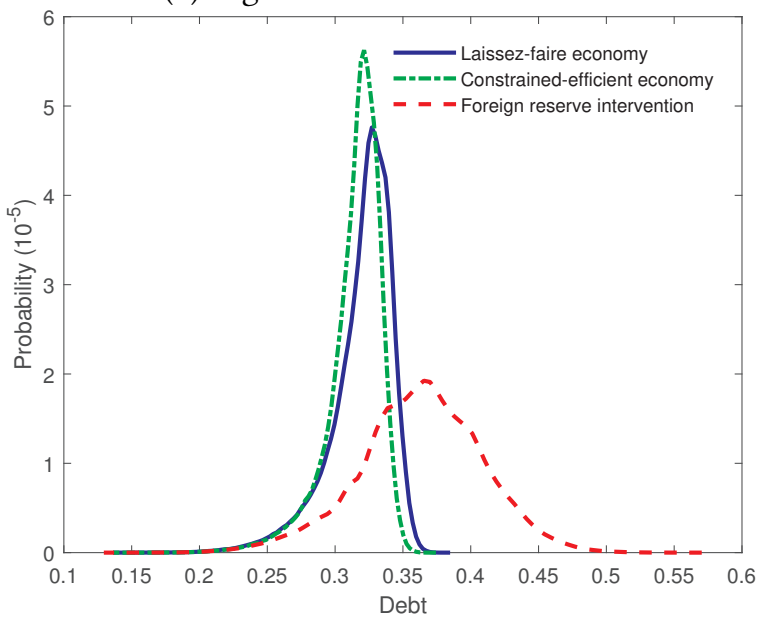

Figure 9: Debt: policy functions and ergodic distributions

Note: In panel (a), the current exogenous states correspond to mean values for output and the financial shock.

Figure 10 further shows how the optimal reserve intervention changes the cyclical properties of private borrowing: panel (a) shows the policy function with respect to income and panel (b) with respect to financial conditions. When income is low, borrowing is increasing in income for both the laissez-faire economy and the economy with the optimal reserve intervention. The reason is that when income is low, the borrowing constraint is binding and higher income helps to relax it. When income is high, however, the two economies differ in the cyclical properties of borrowing: while borrowing is countercyclical under laissez-faire, it is procyclical under the optimal reserve intervention. Under laissez-faire, when the credit constraint does not bind, the economy borrows less when income is high, following a permanent income logic. Under the optimal foreign reserve intervention, in contrast, since the excess borrowing capacity is procyclical in the constrained-efficient allocations, the government accumulates more reserves when output is high, inducing households to take on more debt. On the other hand, panel (b) shows that private borrowing is quite naturally procyclical with respect to financial conditions in both economies.

Our finding that optimal foreign reserve interventions may lead to higher private indebtedness has implications for empirical studies on credit booms and financial crises. In particular, it stresses the importance of taking official reserve dynamics into consideration when determining the role of private credit in predicting financial crises. In our model, the optimal foreign reserve intervention results in higher private indebtedness, yet a lower exposure to financial crises. 
(a) Debt as a function of income

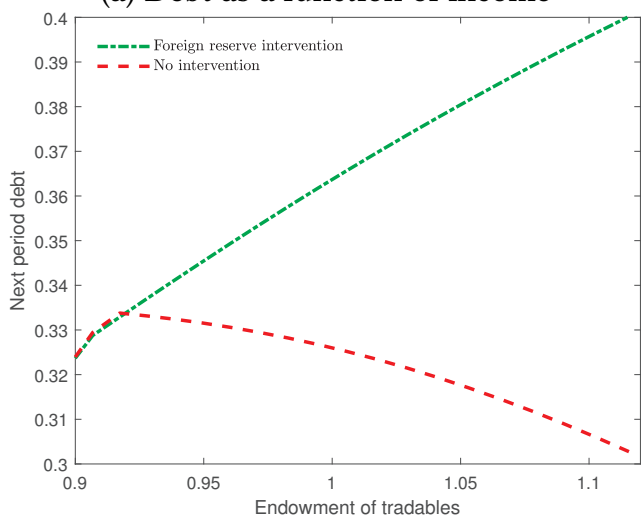

(b) Debt as a function of financial shock

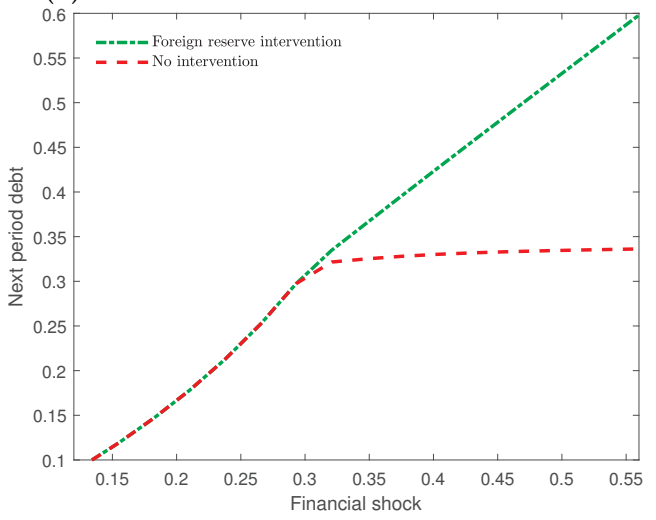

Figure 10: Equilibrium policy function for debt

Note: The initial states correspond to an average debt position. In the left (right) panel, the financial (output) shock is set to its mean value.

\subsection{Accounting for the stylized facts}

We now assess the model's ability to account for the facts $1-3$ outlined in Section $2 .{ }^{20}$ To do so, we simulate the model to generate artificial data comparable with the data used in our empirical analysis of Section 2.

First, we show that the macroprudential motive to accumulate reserves uncovered in the model helps to account for the recent increase in reserves, while being consistent with the simultaneous rise in private external debt observed in the data (fact 1). Using our calibration for Mexico and starting the simulations in 2001, we feed the observed income shocks into the economy and, in addition, calibrate the financial shocks to match the sequence of net foreign assets (NFA) excluding reserves observed in the data. Panel (a) of Figure 11 shows that this exercise makes the model predict a significant increase in reserves, consistent with the increase observed in the data. While the model predicts more volatility in the path of reserves than in the data, its ability to account for the magnitude of the overall increase is quite remarkable. The model is hence able to jointly explain the increase in debt and reserves. Notably, while the debt path was targeted in our simulation (see panel b), the path of reserves was not.

Next, we argue that our model is also consistent with the positive cross-sectional association between reserves and private external debt observed in the data (fact 2). To examine this fact through the lens of our model, we construct 10,000 samples of simulations of 30 years each, and compute averages of reserves and private debt over the last four periods of each sample. Then, following a procedure analogous to that of Figure 2, we compute the difference between this end-of-sample average and the beginning-of-period value. Figure 12 shows a scatter plot in which each dot represents a sample, with the $x$-axis and $y$-axis respectively measuring changes in debt and reserves over the

\footnotetext{
${ }^{20}$ As we discussed above, a key implication of the theoretical analysis is that the model is consistent with fact 4 .
} 
(a) Reserves

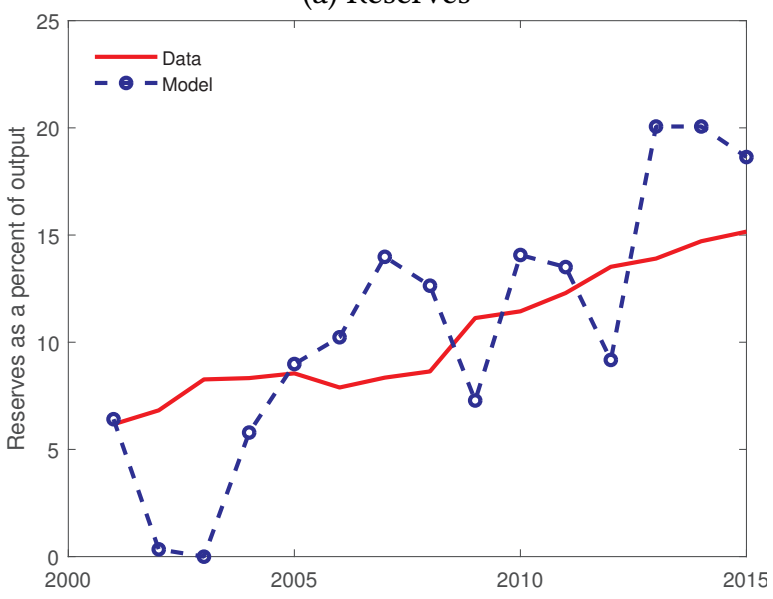

(b) Debt

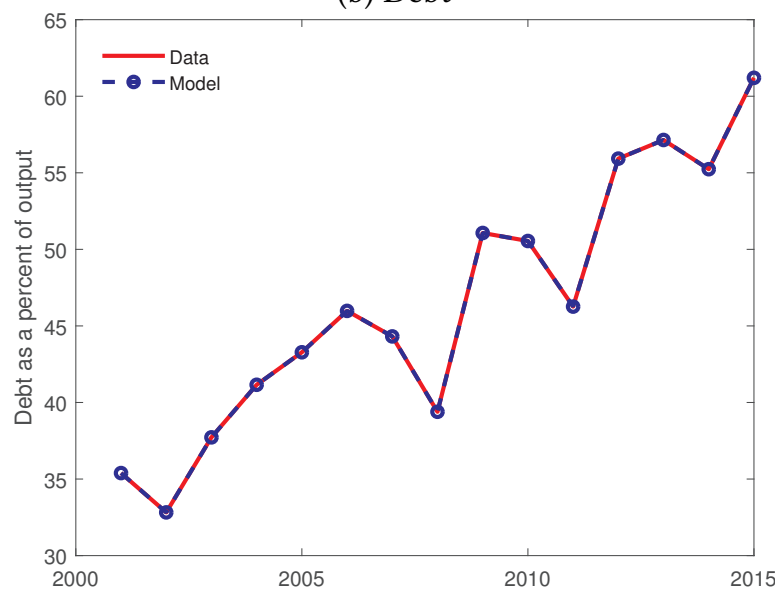

Figure 11: Evolution of reserves and debt, 2001-2015: data and model

Note: Model simulation obtained by feeding observed income shocks and calibrating financial shocks to match sequence of NFA (excluding reserves) observed in the data.

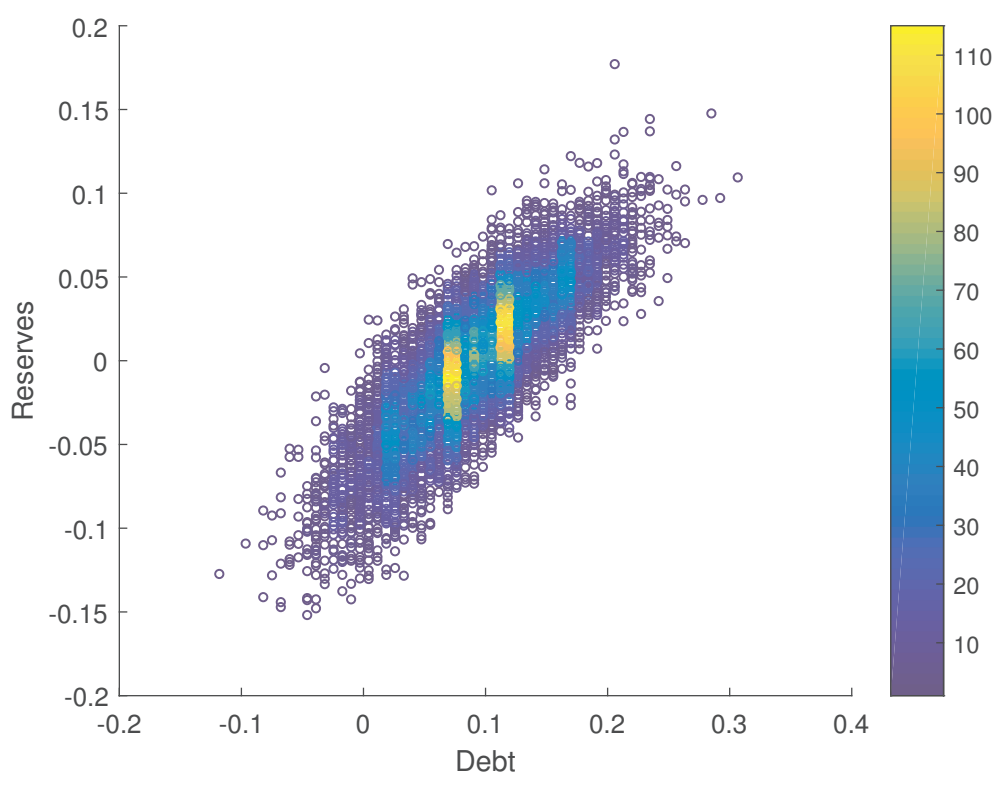

Figure 12: Increase in reserves and private debt

Note: The increase is computed as end of transition minus beginning of transition. Based on 10,000 samples of simulations of 30 years each, with each dot representing a sample. $x$-axis measures difference between average over last four periods and beginning of period value for private debt. $y$-axis measures difference between average over last four periods and beginning of period value for reserves. 
(a) Reserves and output

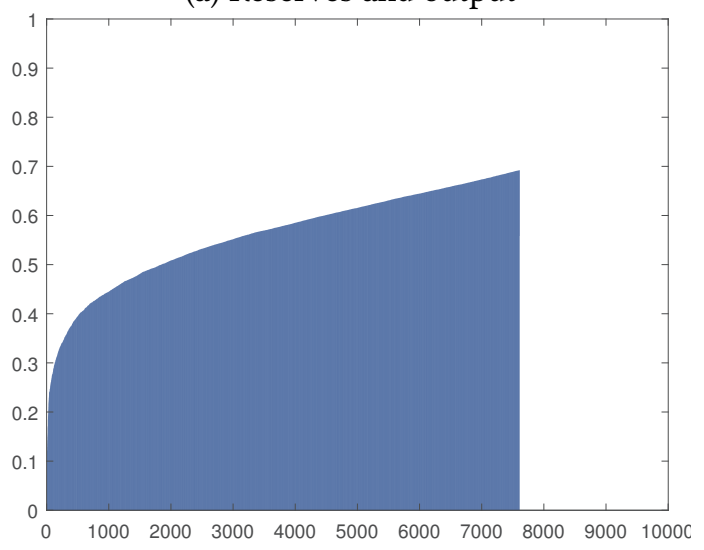

(b) Private debt and output

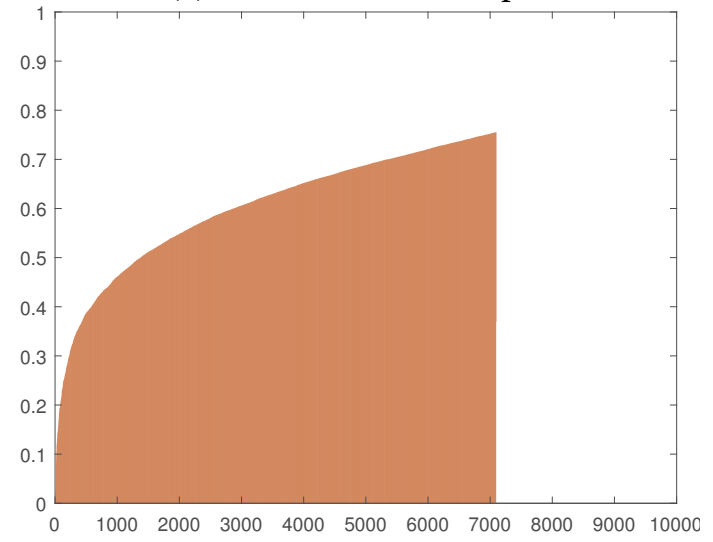

(c) Reserves and private debt

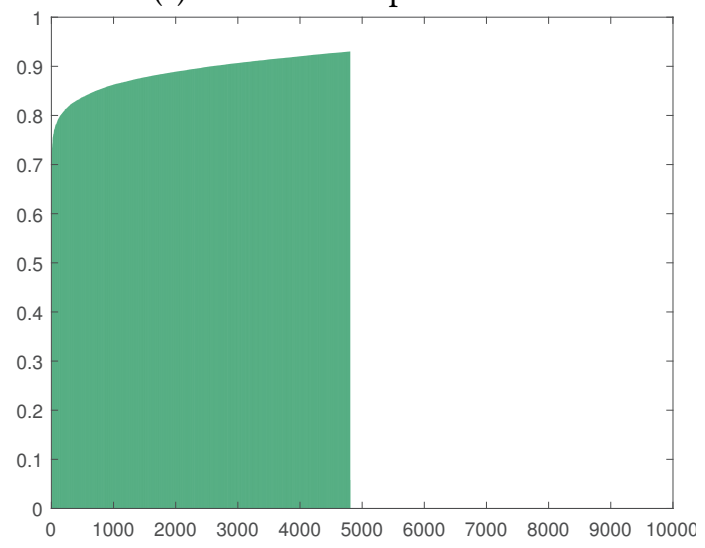

Figure 13: Correlations between changes in reserves and output (panel a), changes in private debt and output (panel b), and changes in reserves and private debt (panel c).

Note: Based on 10,000 samples of simulations of 30 years each, with each vertical bar measuring the correlation between two variables in a given sample. In all samples, we compute reserves, private debt and output. After taking the log of the private debt and ouptut series, we compute first differences. We then calculate and plot the correlations between these changes in reserves, output and private debt.

sample. The figure shows that samples displaying significant increases in reserves also display large increases in private external debt, consistent with fact 2.

Finally, our model generates time-series correlations between the changes in reserves, private external debt, and output in line with those emphasized in our fact 3. For each of our 10,000 samples, we compute time series of first differences of reserves, private debt and output. ${ }^{21}$ We then calculate the correlation between the reserves and output series, between the private debt and output series, and between the reserve and private debt series for each sample. Lastly, we sort these correlations from the lowest to the highest. Figure 13 displays the correlation between the reserve and output

\footnotetext{
${ }^{21}$ We log the private debt and output series, but not the reserve series since there are several occurrences of zero reserves in the samples.
} 
series (panel a), between the private debt and output series (panel b), and between the reserve and private debt series (panel c) for all simulated samples. Panels (a) and (b) suggest that both reserves and private debt appear to be procyclical in the simulated samples. Likewise, panel (c) indicates a positive correlation between reserve and private debt accumulation. These time-series correlation patterns are consistent with patterns observed in the data classified under fact 3.

\section{Conclusions}

This paper articulates a novel rationale for reserve accumulation based on a macroprudential motive. In the theory, reserve accumulation is used to correct a pecuniary externality that generates overborrowing and an excessive exposure to financial crises. We present a simple model that shows that the macroprudential motive for reserve accumulation is qualitatively and quantitatively consistent with both the time-series and cross-sectional patterns of reserve and private external debt accumulation for middle-income countries.

There are several interesting avenues for future research. One would be to apply and further investigate the lessons of our theory for the use of reserve accumulation in models of financial crises that combine aggregate demand externalities and pecuniary externalities. Another would be to extend our theory to allow for frictions in the government's financing of reserve accumulation. We have, in effect, assumed that the central bank can finance reserve accumulation through government transfers. An alternative would be to consider distortionary taxes. A final avenue for future research would be to depart from the assumption of deep-pocket international investors. In this scenario, reserve accumulation would introduce arbitrage losses for the small open economy (Amador et al., 2017; Fanelli and Straub, 2017), and the government would balance these costs against the financial stability benefits uncovered in this paper. 


\section{References}

Aizenman, Joshua and Jaewoo Lee, "International Reserves: Precautionary Versus Mercantilist Views, Theory and Evidence," Open Economies Review, 2007, 18 (2), 191-214.

Amador, Manuel, Javier Bianchi, Luigi Bocola, and Fabrizio Perri, "Exchange Rate Policies at the Zero Lower Bound," 2017. NBER Working Paper No. 23266.

Bacchetta, Philippe, Kenza Benhima, and Yannick Kalantzis, "Capital Controls with International Reserve Accumulation: Can This Be Optimal?”, American Economic fournal: Macroeconomics, 2013, 5 (3), 229-62.

Bengui, Julien and Javier Bianchi, "Macroprudential Policy with Leakages," 2018. NBER Working Paper 25048.

Benigno, G. and L. Fornaro, "Reserve Accumulation, Growth and Financial Crisis," 2012. Mimeo, Centre for Economic Performance, LSE.

Benigno, Gianluca, Huigang Chen, Christopher Otrok, Alessandro Rebucci, and Eric R. Young, "Financial Crises and Macro-Prudential Policies," Journal of International Economics, 2013, $89(2), 453-470$.

Bianchi, Javier, "Overborrowing and Systemic Externalities in the Business Cycle," American Economic Review, 2011, 101 (7), 3400-3426.

_ and Cesar Sosa-Padilla, "Reserve Accumulation, Macroeconomic Stabilization and Sovereign Risk," 2018. Mimeo, Minneapolis Fed.

_ and Enrique G Mendoza, "Optimal Time-Consistent Macroprudential Policy”, fournal of Political Economy, 2018, 126 (2), 588-634.

_ , Juan Carlos Hatchondo, and Leonardo Martinez, "International Reserves and Rollover Risk," American Economic Review, 2018, 108 (9), 2629-2670.

Bocola, Luigi and Guido Lorenzoni, "Financial Crises, Dollarization, and Lending of Last Resort in Open Economies," Technical Report, National Bureau of Economic Research 2017.

Broner, Fernando, Tatiana Didier, Aitor Erce, and Sergio L Schmukler, "Gross Capital Flows: Dynamics and Crises," fournal of Monetary Economics, 2013, 60 (1), 113-133.

Bussiere, Matthieu, Gong Cheng, Menzie Chinn, and Noëmie Lisack, "Capital Controls and Foreign Reserve Accumulation: Substitutes or Complements in the Global Financial Crisis?," 2013. Mimeo, Bank of France. 
Caballero, R. and S. Panageas, "Hedging Sudden Stops and Precautionary Contractions," fournal of Development Economics, 2008, 85(1-2), 28-57.

Calvo, Guillermo A, "Monetary Policy Challenges in Emerging Markets: Sudden Stop, Liability Dollarization, and Lender of Last Resort," Technical Report, National Bureau of Economic Research 2006.

Calvo, Guillermo A., Alejandro Izquierdo, and Rudy Loo-Kung, "Optimal Holdings of International Reserves: Self-Insurance Against Sudden Stop," Monetaria (English Edition), 2013, 1(1), $1-35$.

Cavallino, Paolo, "Capital Flows and Foreign Exchange Intervention," 2018. IMF Working Paper.

Chinn, Menzie D and Hiro Ito, "A New Measure of Financial Openness," Journal of comparative policy analysis, 2008, 10 (3), 309-322.

Clark, Peter Barton, "Optimum International Reserves and the Speed of Adjustment," fournal of Political Economy, 1970, 78 (2), 356-376.

Clower, Robert and Richard Lipsey, "The Present State of International Liquidity Theory," American Economic Review, 1968, 58 (2), 586-595.

Durdu, Ceyhun Bora, Enrique G. Mendoza, and Marco E. Terrones, "Precautionary Demand for Foreign Assets in Sudden Stop Economies: An Assessment of the New Mercantilism," Journal of Development Economics, 2009, 892 (2), 194-209.

Edwards, Sebastian, "The Demand for International Reserves and Exchange Rate Adjustments: The Case of LDCs 1964-1972," Economica, 1983, 50 (199), 269-280.

Fanelli, Sebastian and Ludwig Straub, "Foreign Exchange Interventions and Exchange Rate Management," 2017. Mimeo, MIT.

Flemming, Jean, Jean-Paul L'Huillier, and Facundo Piguillem, "Macro-Prudential taxation in good times," Journal of International Economics, 2019.

Frankel, Jeffrey and George Saravelos, "Can Leading Indicators Assess Country Vulnerability? Evidence from the 2008-09 Global Financial Crisis," fournal of International Economics, 2012, 87 (2), 216-231.

Gabaix, Xavier and Matteo Maggiori, "International Liquidity and Exchange Rate Dynamics," Quarterly fournal of Economics, 2015, 130 (3), 1369-1420.

Heller, Heinz Robert, “Optimal International Reserves," Economic fournal, 1966, 76 (302), 296-311. 
Hur, Sewon and Illenin Kondo, "A Theory of Sudden Stops, Foreign Reserves, and Rollover Risk in Emerging Economies," Journal of International Economics, 2016, 103, 44-63.

Jeanne, Olivier, "Capital Account Policies and the Real Exchange Rate," NBER International Seminar on Macroeconomics, 2012, 9 (1), 7-42.

_ and Anton Korinek, "Managing Credit Booms and Busts: A Pigouvian Taxation Approach," Journal of Monetary Economics, 2018.

_ and Damiano Sandri, "Global Financial Cycle and Liquidity Management," 2017. Mimeo.

_ and Romain Ranciére, "The Optimal Level of Reserves for Emerging Market Countries: A New Formula and Some Applications," Economic fournal, 2011, 121 (555), 905-930.

Kelly, Michael G., “The Demand for International Reserves," American Economic Review, 1970, 60 (4), 655-667.

Kenen, Peter B. and Elinor B. Yudin, "The Demand for International Reserves," Review of Economics and Statistics, 1965, 47 (3), 242-250.

Lorenzoni, Guido, “Inefficient Credit Booms," Review of Economic Studies, 2008, 75 (3), 809-833.

Mendoza, Enrique G., "Credit, Prices, and Crashes: Business Cycles with a Sudden Stop," in S. Edwards and J. Frankel, eds., Preventing Currency Crises in Emerging Markets, University of Chicago Press, 2002.

Obstfeld, Maurice, Jay C Shambaugh, and Alan M Taylor, "Financial Stability, the Trilemma, and International Reserves," American Economic fournal: Macroeconomics, 2010, 2 (2), 57-94.

Rodrik, Dani, “The Real Exchange Rate and Economic Growth," Brookings Paper on Economic Activity, 2008, 39(2), 769-797.

Schmitt-Grohé, Stephanie and Martín Uribe, "Multiple Equilibria in Open Economy Models with Collateral Constraints: Overborrowing Revisited,” 2016. NBER Working Paper No. 22264.

_ and _ , "Is Optimal Capital Control Policy Countercyclical in Open Economy Models with Collateral Constraints?”' IMF Economic Review, 2017, 65 (3), 498-527. 


\section{A Appendix: optimal reserve accumulation policy}

Consider the problem of the government that chooses a state-contingent sequence $\left\{A_{t+1}, T_{t}\right\}_{t=0}^{\infty}$ to maximize welfare:

$$
\begin{aligned}
V\left(b, y^{T}, \kappa\right)= & \max _{b_{t+1}, c_{t}^{T}, A_{t+1}, \mu_{t} \geq 0} \sum_{t=0}^{\infty} \beta^{t} u\left(c\left(c_{t}^{T}, y^{N}\right)\right) \\
& \text { subject to } \\
b_{t}+c_{t}^{T}= & y^{T}+A_{t}+\frac{b_{t+1}-A_{t+1}}{R} \\
\frac{b_{t+1}}{R} \leq & \kappa\left(y_{t}^{T}+\frac{1-\omega}{\omega}\left(\frac{c_{t}^{T}}{y^{N}}\right)^{\eta+1} y^{N}\right) \\
u_{T}\left(c\left(c_{t}^{T}, y^{N}\right)\right)= & \beta R u_{T}\left(c\left(c_{t+1}^{T}, y^{N}\right)\right)+\mu_{t} \\
0= & \mu_{t}\left[\frac{b_{t+1}}{R}-\kappa\left(y^{T}+\frac{1-\omega}{\omega}\left(\frac{c_{t}^{T}}{y^{N}}\right)^{\eta+1} y^{N}\right)\right] \\
\mu_{t} \geq & 0 .
\end{aligned}
$$

Proposition 1. The optimal allocation implemented with $\left\{A_{t+1}, T_{t}\right\}_{t=0}^{\infty}$ achieves the same utility as the constrained-efficient allocations. Moreover, the optimal policy is time consistent.

Proof. The key is to show first that the last three constraints in the government's problem are slack. Once we do this, it is straightforward to see that since $A_{t+1} \geq 0$, the problem of the government is effectively reduced to the same as in the constrained-efficient problem (9) and is time consistent.

Ignoring the last three constraints and deriving the first-order condition with respect to $b_{t+1}$, we obtain

$$
u_{T}(t)=\beta R \mathbb{E}_{t}\left(u_{T}(t+1)+\hat{\mu}_{t+1} \Psi_{t+1}\right)+\hat{\mu}_{t}\left(1-\Psi_{t}\right)
$$

where we use $\hat{\mu}_{t}$ to denote the Lagrange multiplier on the borrowing constraint for the government problem and distinguish it from the Lagrange multiplier on the household problem.

Under Assumption 1, we have $\Psi_{t}<1$. Since $\hat{\mu}_{t+1} \geq 0$ and $\Psi_{t+1} \geq 0$, we have

$$
u_{T}\left(c\left(c_{t}^{T}, y^{N}\right)\right)-\beta R \mathbb{E}_{t}\left(u_{T}\left(c\left(c_{t+1}^{T}, y^{N}\right)\right) \geq \hat{\mu}_{t+1} \Psi_{t+1}\right.
$$

Set $\mu_{t}=u_{T}\left(c\left(c_{t}^{T}, y^{N}\right)\right)-\beta R \mathbb{E}_{t}\left(u_{T}\left(c\left(c_{t+1}^{T}, y^{N}\right)\right)\right.$. It follows then that (17) and (19) are satisfied. 
We are left to show that the complementary slackness condition (19) is satisfied. To see this, notice that if $\left(b_{t+1}, A_{t+1}\right)$ solve (14) subject to (15)-(16), we have that $\left(b_{t+1}+\Delta, A_{t+1}+\Delta\right)$ also achieve the same utility and are feasible as long as $\frac{b_{t+1}}{R}-\kappa\left(y^{T}+\frac{1-\omega}{\omega}\left(\frac{c_{t}^{T}}{y^{N}}\right)^{\eta+1} y^{N}\right) \geq 0$. Without loss of generality, we can therefore set $\frac{b_{t+1}}{R}-\kappa\left(y^{T}+\frac{1-\omega}{\omega} c_{t}^{T}\right)=0$, and hence (19) is satisfied. 